\title{
The Russian banking sector: new development trends
}

\author{
Natalya Mashkina*, Ekaterina Selyutina and Anna Minaeva \\ Southwest State University, 305040 Kursk, Russia
}

\begin{abstract}
The article examines the key trends in the banking system of the Russian Federation in 2017-2019. The efficiency of the use of domestic financial resources and the intensity of accumulation processes largely determine the level of socio-economic development of the state, which confirms the key role of banks and the banking sector in the development of the national economy. Although the Russian banking sector is experiencing rapid growth, it still does not reach a sufficient level of development of the competitive environment and market discipline, which negatively affects the quality of banking services. The aim of the study is a comprehensive analysis of current trends in the development of the banking sector of the Russian Federation over the past three years. During the study, comparison methods and economic and statistical methods were used. The tasks of the work are to identify existing problems in the Russian banking sector and its prospects. The result of this work was a study of key indicators of the banking system of the Russian Federation in 2017-2019. This study analyzed the dynamics of the number of credit institutions, financial results of the banking sector, as well as the volume of credits and deposits of legal entities and individuals. The main conclusion of the work was that despite the active development of the Russian banking system in recent years, there are still problems that need to be solved. Global processes and challenges, such as the coronavirus pandemic in 2020 and related restrictions, have a negative impact on the financial sector both in Russia and globally. This also includes foreign sanctions. In these circumstances, the subsequent development of the domestic banking sector will largely depend on the development of the situation with coronavirus and Russia's diplomatic relations.
\end{abstract}

\section{Introduction}

The problems of studying the impact of the banking system on the socio-economic development of the state are quite relevant at the present stage of economic development. The role of commercial banks in this process is determined, first of all, by the investment component, as a result of the impact of which the necessary financial conditions are created and developed, in which economic entities (enterprises, households and the state) exist and function, and which contribute to the increase in added value, the growth of profit of

* Corresponding author: t.natusia@yandex.ru 
organizations and the income of the population [4]. At the same time, the banking sector plays another key role by investing capital in the development of the economy, both regional and national, to generate income. At the same time, it is important to invest in profitable economic and socially significant projects, thus points of socio-economic growth are formed.

Among the trends in the development of the Russian banking sector at the present stage, one can distinguish its rapid rise. This allows us to expand and open new opportunities to expand the offer and improve the quality of banking services in Russia. Despite this, the Russian banking sector still does not reach the required level of development of the competitive environment and market discipline, which has a negative impact on the quality of banking services.

As experts say in their research, the main problems that hinder the development of the banking sector in the Russian Federation and deserve due attention are [8]:

- low capitalization;

- limited capabilities of the state's banking system;

- regional and sectoral imbalances in the Russian economy.

The prospects for the development of the banking sector of the Russian Federation are influenced by both internal and external factors. The first of them are, first of all, the solution of the above-mentioned problems, and the second are the global situation with the financial and economic crisis, which has a great negative impact on the state of the banking sector in the Russian Federation.

By the beginning of the pandemic, in the spring of last year, almost all banks were providing financial services online. But with the introduction of the self-isolation regime, it was urgently necessary to digitize the product lines and transform the service into an online format. In addition, it was not necessary to delay the remote opening of accounts for new customers - they could go to competitors.

Therefore, the vast majority of banks began to actively work on expanding the functionality of mobile applications, and this became the main element of the digital transformation of banking services. At the same time, the emphasis is not only on new technologies, but also on constant updating and modernization - now this directly affects the bank's competitiveness. Today, one can not only remotely get a banking product, but also get certificates, statements, and transaction histories through mobile apps. Therefore, it is quite natural that the convenience of applications began to seriously affect the customers' assessment of the quality of service in general.

Now the Faster Payments System (FPS) has become another key driver of mobile banking development, and this is directly related to the improvement of mobile banking applications. According to the Central Bank, as at $1^{\text {st }}$ of March 2021, 214 banks have already become participants in the FPS, and more than $178 \mathrm{mln}$. transfers worth more than 1.2 trl. rbl. have been made in the system. For comparison: in the first nine months of 2020 , Russians made 6 bln. transfers worth 30.9 trl. rbl. by using cards. And by 2023, according to the forecasts of the Central Bank, the share of money transfers through the FPS should grow from last year's $15 \%$ to $25 \%$ [16].

One of the most actively developing areas in banking applications is the management of customer funds. Banks strive to automate this process as much as possible by adding, for example, a savings account and other services to the app that help us plan our budget by selecting individual products. This becomes the main indicator of their digital development.

Biometric data is also expected to appear in mobile applications in 2021. And, it is quite obvious that credit institutions will continue to saturate mobile banks with new products and simplify their use as much as possible in the expectation of a mass audience.

It should be noted that Russia is among the top 10 countries in terms of digitalization of banks. At five of the six stages of interaction with the client, Russian banks exceed the 
global average, as evidenced by the new international review of the digitalization of commercial banks, which was compiled by the Deloitte international network. After communicating with 318 banks in 39 countries as secret buyers, the company's experts and analysts have found out that Russian banks are among the world leaders in the level of digitalization of their services [17].

Thus, we view that, focusing on today's customer needs, banks are actively implementing digitalization, successfully demonstrating the ability to integrate into new circumstances.

\section{Materials and Methods}

The problems of the development of the banking sector always remain relevant and are constantly in the focus of attention of domestic scientists, experts and analysts. Thus, in his article [6] the Russian scientist O. I. Lavrushin analyzes and gives a general assessment of innovative technologies, their positive and negative sides, in his article the author reveals the problems that largely hinder the development of the banking sector. Other researchers A. V. Egorov, E. N. Chekmareva, S. A. Zhabin express their opinion that the risk appetite of commercial banks, enterprises and households is still low, which constrains the economic activity of economic entities [3]. The issues of improving the economic model of the system of credit institutions and the development of the banking services market are studied in many works of domestic authors.

An analysis of the state of the Russian financial sector and banking system, trends in the development and transformation of the main activities of credit institutions allows us to identify a number of serious problems. Let us consider some of them that are most important.

The development of the banking business is constrained mainly by the lack of reliable borrowers, as well as the inability to generate sufficient capital to cover the ever-increasing risks, which leads to an excess of low-income liquid assets that increase the pressure on the profitability of a large number of commercial banks [2]. Thus, the share of unprofitable credit institutions has reached $18 \%$ in recent years, which indicates the incompleteness of the process of rehabilitation of commercial banks in the territory of the Russian Federation. It should be mentioned that the crisis of business models is increasingly faced by banks with the average amount of assets, which will probably lead to a reduction in their presence in the banking services market in the future [5].

In 2020, the Central Bank of Russia continues to adhere to its strategy, which has been successfully implemented for many years, the essence of which is to improve the banking market by revoking licenses from insolvent credit institutions [12]. According to the "Expert RA" agency, 38 of the almost 400 banks may have their licenses revoked in 2020 [13].

We cannot fail to mention the negative impact of the consequences of the coronavirus pandemic on the banking sector. The situation that gripped the world's economies in 2020 came as a shock to both supranational structures (demonstrating their amorphous nature and inability to solve problems of this magnitude) and to national governments. As a result, the first months of countries' lives in the context of the spread of the pandemic and the associated restrictions showed that the globalized world was not able to respond to such environmental challenges. Each state will adapt to the new realities and find ways out of the crisis situation individually. It should be noted that this situation has the greatest impact on the financial and economic sector [11].

Studying the trends in the development of the Russian banking sector, one should also take into account the impact of Western sanctions on the country's economy. 
If the geopolitical situation worsens, Western countries will tighten the policy of sanctions until Russia is disconnected from the global payment system. As a result, the development of the banking sector will directly depend on the diplomatic relations of the Russian Federation with other countries. And if within the framework of the first factor, it is possible to make a long-term forecast of the development of the situation, then the second factor is very problematic for a long-term assessment, which means that the banking system of the Russian Federation in particular and the entire economy as a whole at the present stage of development are under constant pressure due to the inability to predict the situation within the framework of the sanctions policy of Western countries [1].

\section{Results and Discussion}

The practical part of our research should begin with the analysis of the dynamics of the number of Russian credit institutions for the period 2017-2019 (Table 1).

Table 1. Dynamics of the number of credit institutions in the Russian Federation from 2017 to 2019.

\begin{tabular}{|c|c|c|c|c|}
\hline Indicators & $\mathbf{2 0 1 7}$ & $\mathbf{2 0 1 8}$ & $\mathbf{2 0 1 9}$ & $\begin{array}{c}\text { Absolute deviation of 2019 } \\
\text { from 2017 (+,-) }\end{array}$ \\
\hline Credit organizations, units & 561 & 484 & 444 & -117 \\
\hline Banks, units & 517 & 440 & 405 & -112 \\
\hline $\begin{array}{c}\text { The share of banks in the number } \\
\text { of credit institutions, \% }\end{array}$ & $92 \%$ & $91 \%$ & $91 \%$ & -1 \\
\hline $\begin{array}{c}\text { Branches of credit organizations in } \\
\text { the Russian Federation, units }\end{array}$ & 890 & 709 & 631 & -259 \\
\hline Branches abroad, units & 6 & 6 & 5 & -1 \\
\hline
\end{tabular}

As can be seen from Table 1, in 2017-2019, 117 credit organizations were liquidated, including 112 fewer banks. We also see that banks account for more than $90 \%$ of the structure of credit institutions. Branches in the Russian Federation decreased by 259 units, and branches abroad decreased by 1 unit. The negative dynamics of credit institutions is clearly shown in Figure 1.

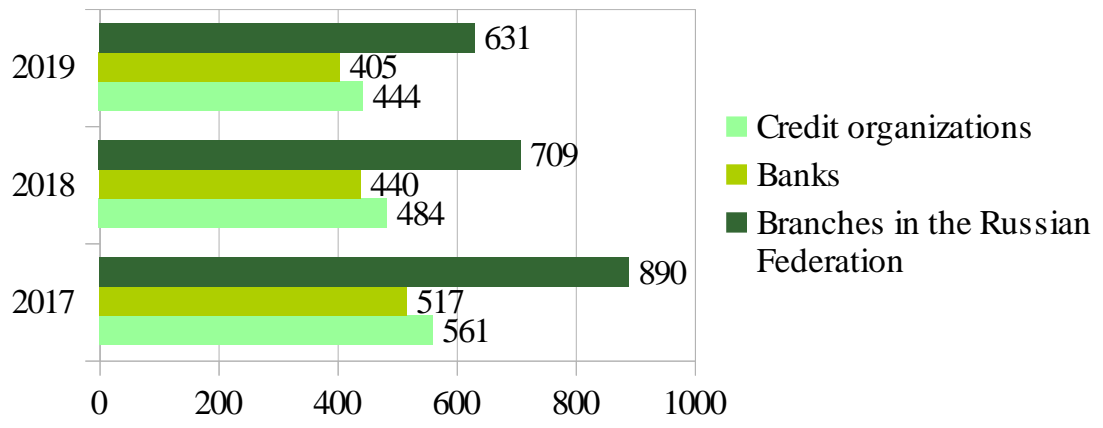

Fig. 1. Dynamics of the number of credit institutions in the Russian Federation from 2017 to 2019 , units.

The situation related to the revocation of banking licenses in 2019 was more calm than in previous years, although their number remained relatively high. In 2019, 28 licenses were revoked, and 12 banking organizations voluntarily lost their licenses. It should be 
noted that in 2018, 60 banks lost their licenses by force, another 17 banks lost their licenses voluntarily, and in 2017 - 51 and 11 , respectively.

Thus, there was fewer forced revocations of bank licenses, and more voluntary ones, on the contrary. First of all, this was due to an increase in the capital requirements of banks and their division into two levels: with a basic and universal license.

Another trend in the development of the banking sector in recent years is the growth of total capital and profit, as can be seen in Figure 2. In 2017-2019, the capital of the banking sector increased by $882 \mathrm{bln}$. rbl., or by $9.4 \%$. Profit growth amounted to $415 \mathrm{bln}$. rbl., or $44.6 \%$. According to the Bank of Russia, in 2019, the profit reached a record high. These results was mainly related to the reduction in the cost of forming reserves, which was of a technical nature.

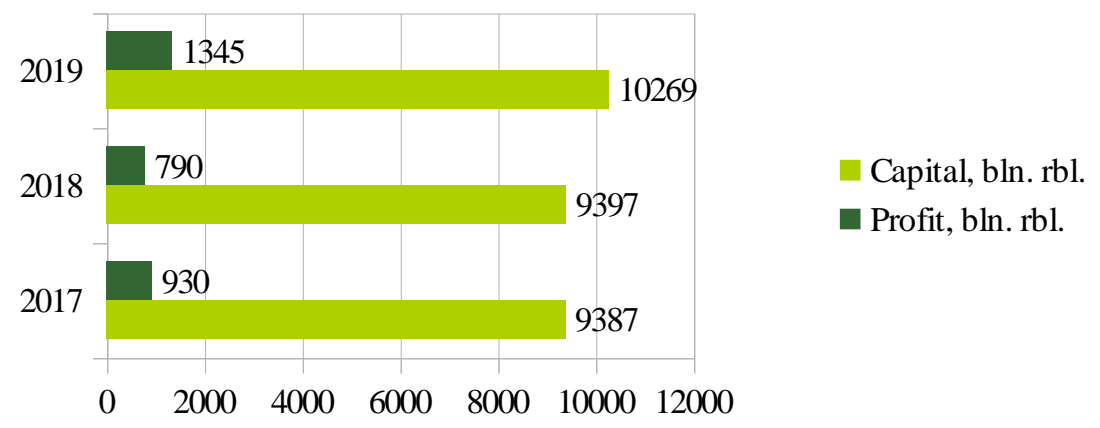

Fig. 2. Key performance indicators of the banking sector of the Russian Federation from 2017 to 2019.

Consider the dynamics of deposits of individuals and legal entities for the period 2017 2019 (Table 2).

Table 2. Dynamics of the volume of deposits of the banking sector in the Russian Federation from 2017 to 2019.

\begin{tabular}{|c|c|c|c|c|c|}
\hline Indicators & $\mathbf{2 0 1 7}$ & $\mathbf{2 0 1 8}$ & $\mathbf{2 0 1 9}$ & $\begin{array}{c}\text { Absolute } \\
\text { deviation of 2019 } \\
\text { from 2017 (+,-) }\end{array}$ & $\begin{array}{c}\text { Growth rate } \\
\mathbf{( 2 0 1 9} \text { in \% to } \\
\mathbf{2 0 1 7})\end{array}$ \\
\hline $\begin{array}{c}\text { Deposits of individuals, } \\
\text { mln. rbl. }\end{array}$ & 24200322 & 25987406 & 28460229 & +4259907 & $117,6 \%$ \\
\hline $\begin{array}{c}\text { Deposits of legal } \\
\text { entities, mln. rbl. }\end{array}$ & 17900432 & 21651970 & 21683994 & +3783562 & $121,1 \%$ \\
\hline
\end{tabular}

According to Table 2, deposits of individuals and legal entities show almost the same growth rate, they increased by $17.6 \%$ and $21.1 \%$, respectively. This is due to the fact that individuals do not have a sufficient variety of alternatives for investment, and deposits are a more reliable and convenient way to store and accumulate savings for the population. The growth of deposits of legal entities may indicate the presence and increase in their temporarily available funds. The dynamics of deposits is most clearly shown in Figure 3. 


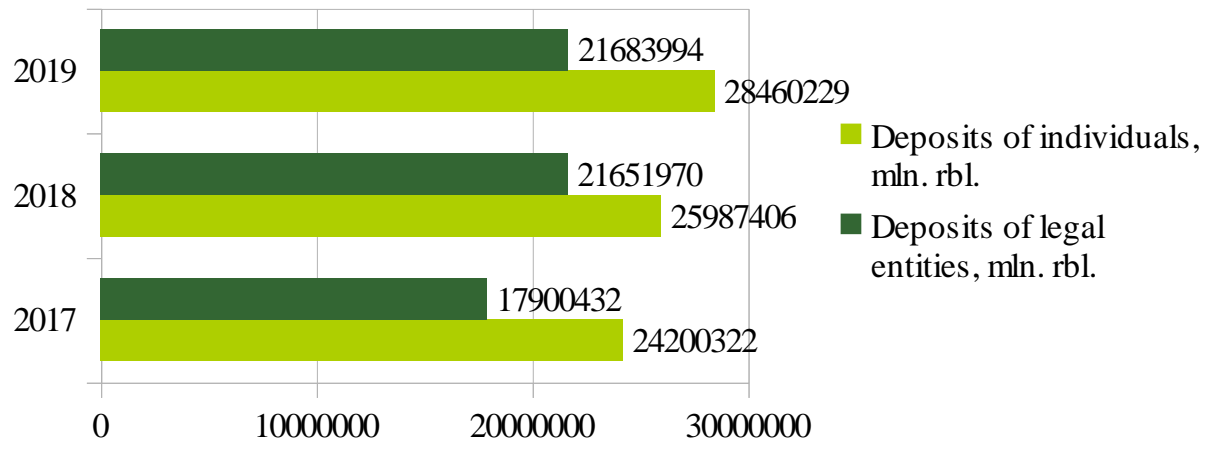

Fig. 3. Dynamics of the volume of deposits of the banking sector in the Russian Federation from 2017 to 2019 .

According to Table 3, loans issued to both individuals and legal entities have a positive trend. The highest growth rate is observed for loans to individuals - the volume of the indicator increased by $44 \%$. This fact to some extent allows us to judge the increase in income of the population. The growth of lending to legal entities is not so high, only $15.4 \%$, which is explained by the rise in the price of credit products in the banking sector, associated with an increase in the level of credit risks.

The highest growth rate is observed for loans to individuals - the volume of the indicator increased by $44 \%$. This fact to some extent allows us to judge the increase in income of the population. The growth of lending to legal entities is not so high, only $15.4 \%$, which is explained by the rise in the price of credit products in the banking sector, associated with an increase in the level of credit risks.

Table 3. Volume of lending to legal entities and individuals in the Russian Federation from 2017 to 2019.

\begin{tabular}{|c|c|c|c|c|c|}
\hline Indicators & $\mathbf{2 0 1 7}$ & $\mathbf{2 0 1 8}$ & $\mathbf{2 0 1 9}$ & $\begin{array}{c}\text { Absolute deviation } \\
\text { of 2019 from 2017 } \\
(+,-)\end{array}$ & $\begin{array}{c}\text { Growth rate } \\
\mathbf{( 2 0 1 9} \text { in \% to } \\
\mathbf{2 0 1 7})\end{array}$ \\
\hline $\begin{array}{c}\text { Loans to legal entities, } \\
\text { bln. rbl. }\end{array}$ & 33820 & 38011 & 39035 & +5215 & $115,4 \%$ \\
\hline $\begin{array}{c}\text { Loans to individuals, bln. } \\
\text { rbl. }\end{array}$ & 12174 & 14901 & 17475 & +5301 & $144 \%$ \\
\hline
\end{tabular}

These indicators are clearly shown in Figure 4. 


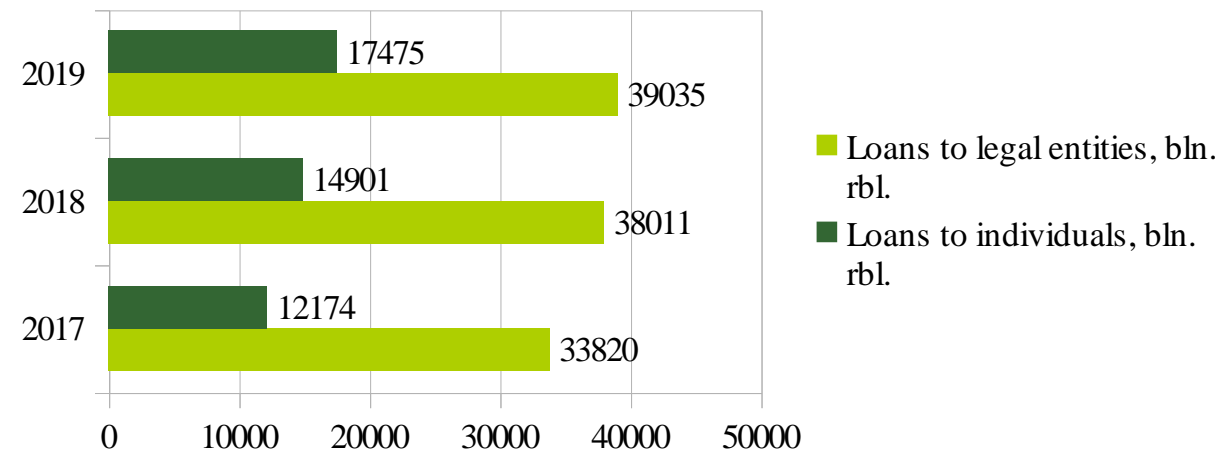

Fig. 4. Volume of lending to legal entities and individuals in the Russian Federation from 2017 to 2019.

Among the five leading banks in terms of the loan portfolio are Sberbank, VTB, Gazprombank, Rosselkhozbank and Alfa-Bank (Table 4). Sberbank has held the first position in this rating for three years, VTB - the second, Gazprombank - the third. VTB 24 Bank was ranked 4th in 2017, but has been absent from the table since 2018, as it merged with VTB.

Table 4. Leading banks in terms of the loan portfolio in the Russian Federation from 2017 to 2019.

\begin{tabular}{|c|c|c|c|c|c|c|}
\hline \multirow{2}{*}{ Name } & \multicolumn{2}{|c|}{2017} & \multicolumn{2}{c|}{2018} & \multicolumn{2}{c|}{2019} \\
\cline { 2 - 7 } & Bln. rbl. & $\begin{array}{c}\text { Place in the } \\
\text { rating }\end{array}$ & Bln. rbl. & $\begin{array}{c}\text { Place in the } \\
\text { rating }\end{array}$ & Bln. rbl. & $\begin{array}{c}\text { Place in the } \\
\text { rating }\end{array}$ \\
\hline Sberbank & 15879,8 & 1 & 18589,6 & 1 & 19468,5 & 1 \\
\hline VTB & 5574,4 & 2 & 9550,9 & 2 & 9890,0 & 2 \\
\hline Gazprombank & 3783,7 & 3 & 4192,2 & 3 & 4430,9 & 3 \\
\hline VTB 24 & 2059,3 & 4 & - & - & - & - \\
\hline Rosselkhozbank & 1892,4 & 5 & 2155,7 & 4 & 2342,8 & 4 \\
\hline Alfa-Bank & 1612,3 & 6 & 2043,5 & 5 & 2292,8 & 5 \\
\hline
\end{tabular}
2019.

Thus, all of the above banks have maintained their position in the rating during 2017-

\section{Conclusions}

The conducted research allows us to judge the main trends in the banking sector of the Russian Federation in 2017-2019 and draw the following conclusions:

- the banking sector is actively developing, its rapid growth has been observed in recent years, which opens up new opportunities to expand the offer of banking services;

- among the main problems of the domestic sector, one can note the low capitalization, regional imbalances in the development of the economy;

- the process of rehabilitation of Russian banks, successfully carried out by the Bank of Russia, is still not completed and will require a large number of license revocations from unprofitable banks in 2020; 
- the situation with the coronavirus pandemic in 2020 did not bypass the banking system, as states were not ready for such global problems and were not able to fully eliminate its consequences. Moreover, it will continue to have a negative impact on the economy for a long time, as the second wave of coronavirus requires new and more serious restrictions from world governments;

- there is an increase in the volume of loans and deposits for both individuals and legal entities;

- there is a record rate of growth in the banking sector's profit by 2019 , due to a reduction in reserves for possible losses.

Despite the fact that thanks to government measures, the domestic banking system has the ability to resist the imposed and supported sanctions, problems with financing and obtaining access to international loans still persist [7].

In this situation, the institutions of the banking sector should pay attention to the domestic market, search for domestic customers and actively participate in increasing the profitability of their activities in order to build a high-quality and high-yield portfolio in the future.

The development of modern banking technologies is also important. Moreover, it is necessary not only to actively implement them and contribute to improving the level of literacy of the population in this direction, but also to continue working towards strengthening security. Although, according to the research [14], many people are quite aware of the security rules of Internet banking, the crime rate in this area (fraud) is still quite high.

It should be noted that Moody's has raised the forecast for the banking sector of the Russian Federation for 2021 from negative to stable, thanks to the recovery in oil prices and the gradual lifting of restrictions related to the coronavirus. For example, lending to the banking sector is expected to grow by about $12 \%$, compared with the same value of $14 \%$ in the previous year, when banks issued state-subsidized loans to support borrowers affected by the pandemic. It should be noted that the profitability, funding and liquidity of credit institutions in the Russian Federation will remain at a stable level, but the system-wide ratio of loans to deposits will remain below 100\%. Rising inflation and a decline in the appeal of fixed-income individual deposits are also expected to cause a structural shift in bank financing by accelerating the outflow of savings from term deposits to current accounts and securities markets.

The year 2020 has become a challenge for all sectors of the economy, and it is difficult to predict what changes will face the banking sector in the future. Now the Russian banking sector is operating in conditions that are constantly changing, so Russian banks have a choice to be ahead of everyone or to lag behind. Banks that do not use modern technologies lose their competitive advantages. Banks around the world position themselves as technology companies. Although not all banks adhere to this strategy, it shows a breakthrough in the development of the industry.

The introduction of digital technologies and the analysis of large amounts of data allows us to create fundamentally new banking products. "Digital" and technology companies are entering the financial services market, and large traditional banks are creating ecosystems, focusing on the most profitable components within the banking value chain and beyond. Large and technologically advanced banks are creating their own ecosystems that open up new, unconventional sources of income. These trends determine the direction of the industry's development, and it is important for banks to take them into account in their strategies [18].

The banking sector is a key link in the country's economy. However, there are still problems that need to be solved, as well as global processes that inevitably have a negative impact on the activities of commercial banks, such as, for example, the coronavirus 
pandemic. The impact of foreign sanctions on the economy as a whole and on the banking sector should also be noted. Here, further developments will depend on Russia's diplomatic relations with these countries.

\section{References}

1. O. V. Aseev, N. A. Mashkina, A. E. Veliev, Bulletin of the Kursk state agricultural Academy, 1, 141 (2019)

2. T. N. Polyakova, E. S. Belyaeva, O. V. Belyaeva, N. A. Mashkina, E. Yu. Yakimova, Proceedings of the 34rd International Business Information Management Association Conference, 11966 (2019)

3. A. V. Egorov, E. N. Chekmareva, S. A. Zhabina, Banking, 1, 28 (2017)

4. D. A. Kazantseva, Management consulting, 9, 121 (2019)

5. N. H. Kurbanov, V. G. Shiyko, Economic Sciences, 166, 118 (2018)

6. O. I. Lavrushin, Banking, 6, 36 (2017)

7. L. V. Levchenko, Yu. S. Silantev, Economic and legal issues, 4(142), 54 (2020)

8. E. D. Lepeshkina, S. A. Popova, I. A. Chekhov, Innovative science in the globalizing world, 1(9), 41-43 (2019)

9. N. A. Mashkina, V. E. Agarkova, CITISE, 1(23), 216-225 (2020)

10. E. Belyaeva, O. Belyaeva, N. Mashkina, T. Polyakova, Proceedings of the 33rd International Business Information Management Association Conference, 1586 (2019)

11. A. D. Osinin, Humanities. Bulletin of the financial University, 3, 142 (2020)

12. O. A. Sinichenko, Eurasian Union Of Scientists, 3-5(72), 21 (2020)

13. Expert RA: $10 \%$ of Russian banks are at risk - the health index has increased, https://www.raexpert.ru/researches/publications/bfm_mar06_2020/

14. J. A. Ojeniyi, E. O. Edward, S. M. Abdulhamid, International Journal of Education and Management Engineering, 2, (2019)

15. A. K. Oteshova, N. A. Prodanova, T. L. Melekhina, N. K. Gavrilieva, Webology, 1, 315 (2020)

16. The official website of the Central Bank of Russia, https://www.cbr.ru/

17. Russia has entered the top 10 countries for digitalization of banks, https://www.vedomosti.ru/economics/articles/2020/10/11/842808-rossiya-voshla

18. S. K. Yeshugova, A. K. Dorgushaova, S. K. Chinazirova, R. V. Kostenko, New Technologies, 4, 228 (2019) 